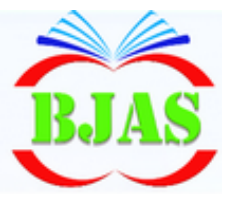

ISSN $1814-5868$
Available online at http://bajas.edu.iq

https://doi.org/10.37077/25200860.2021.34.1.05

College of Agriculture, University of Basrah

Basrah J. Agric. Sci., 34(1): 49-59, 2021

\section{Basrah Journal of Agricultural Sciences}

E-ISSN: 2520-0860

\title{
Mathematical Model for Evaluating Slippage of Tractor Under Various
}

\section{Field Conditions}

\author{
Salim A. Almaliki*, Majed S. Himoud \& Sadiq J. Muhsin \\ Department of Agriculture Machines and Equipment, College of Agriculture, University of \\ Basrah, Iraq \\ *Corresponding author-mail: Salim.bander@uobasrah.edu.iq \\ Received 22 May 2020; Accepted 28 September 2020; Available online 9 February 2021
}

\begin{abstract}
The slippage is an essential criterion for evaluating the fuel consumption and the field performance of tractor. The objective of this research was to develop mathematical models using Design Expert software for modelling and predicting slippage of the CASE JX75T tractor (India manufacture) under operational field conditions. In this research, a chisel plough was used as a loading tool for the tractor under four levels of ploughing depths, with three levels of speed and two levels of cone index (CI) in silty clay soil texture. The experiments were carried out in the site of Basrah University. The results obtained from the fieldwork were analysed to evolve mathematical models and equations to predict and evaluate the performance of the tractor when the slippage occurred. According to the obtained results, the single effects of the parameters (CI, tillage depth, and forward speed) on the slippage were highly considerable $(\mathrm{P}<0.0001)$. Moreover, the interaction of the parameters were significant $(\mathrm{p}<0.05)$. The slippage of tractor increased by 187 and $116 \%$ with increasing ploughing depth up to $25 \mathrm{~cm}$ and forward speed up to $1.53 \mathrm{~m} . \mathrm{s}^{-1}$, respectively. On the other hand, tractor slippage reduced by $34 \%$ when CI increased up to $980 \mathrm{kPa}$. The data analysis showed that the developed model has passable imitation ability and excellently executed in confront of the actual data. This confirms the accuracy of the model for predicting tractor slippage under different fieldworks.
\end{abstract}

Keywords: Design Expert software, Modelling, Cone index.

\section{Introduction}

The slippage is most affecting factor on assessing tractive performance of tractors and proper operation of the implements. Wheel slip occurs when a tractor pulls a load which leads to deformation of the traction device and shear within the topsoil. Hence, diminution of distance traveled and/or speed (ASAE, 2003). The slippage of tractors relates to the utilization specification of driving wheels, the physical and mechanical criteria of soil. Slippage also depend on the interaction between tractive device and soil. The slippage of tractor is an essential parameter for assessing the wasted energy and traction efficiency of a tractor. The process of controlling the tractor-implement system is one of the essential factors that reduces exhausted fuel by $10 \%$ (Karparvarfard \& Rahmanian-Koushkaki, 2015). 
Several studies have indicated that the tractor power dissipation can be reached to more than $50 \%$ due to slippage and rolling resistance. This leads to deplete the tires and compacts the soil which reflected negative on crop production (Zoz \& Grisso, 2003; Šmerda \& Čupera, 2010; Barbosa \& Magalhaes, 2015; Taghavifar \& Mardani, 2015; Kumar et al., 2017). As per the prior studies, it is recommended that driving wheel slippage should not exceed $16 \%$, otherwise, decreasing in field performance, raise in fuel consumption and increasing in deformation of soil structure would be inevitable (Battiato \& Diserens, 2013; Damanauskas \& Janulevicius, 2015; Damanauskas et al., 2015; Almaliki, 2017). Researchers showed that agricultural tractors operating in off road are most efficient, when the drive wheel slippage is in the range of $8-12 \%$ (Aday et al., 2011; Damanauskas et al., 2015; Lee et al., 2016; Battiato \& Diserens, 2017). Wong (2009) noticed that if slip of drive wheel decreases to $5-7 \%$, energy consumption increases per unit of performed work because of the traction power is not exploited, correctly. The tillage depth and forward speed are playing substantial role on the determination in slippage of off-road vehicles (Shafaei et al., 2019). They used intelligent imitation techniques to simulate the slippage of tractor under various field conditions which includes adaptive fuzzy neural inference system (ANFIS) and artificial neural network (ANN).

The effect of dual combination of forward speed and tillage depth was more effective than that of other combinations of the parameters on the wheel slip. Moitzi et al. (2014) tried to demonstrate the relationship between fuel consumption and field capacity performance under different field conditions.
They found increase in fuel consumption and decrease in field capacity performance with increasing slippage of tractor. For development and improvement efficiency of agricultural operation and making agricultural machinery to work at optimum performance, many researchers were toward the investigation of the effect of field parameters and soil condition on the machinery's performance (Muhsin, 2010; Almaliki et al., 2016; Almaliki, 2018; Shafaei et al., 2018; Almaliki et al., 2019). The realization of this importance led to the evolution of many arithmetical models to simulate the performance of machinery when performing field works.

The objective of this study was to present mathematical model for predicting slippage of tractor (model: CASE JX75T) under different field conditions including different depths, speeds and cone indices. The Response Surface Method (RSM) was applied to produce a mathematical model and analyze the acquired data using Design-Expert Software 8.0.6.1.

\section{Materials \& Methods}

\section{Soil investigations}

An experimental field sited at University of Basrah located in $33^{\circ} 30^{\prime} 19^{\prime \prime} \mathrm{N} 44^{\circ} 47^{\prime} 54^{\prime \prime}$ E, Basrah province, Iraq, was used to carry out the tests. The experimental field had silty clay texture (49\% silt, $20 \%$ sand, and $31 \%$ clay) and plane topography. The bulk density and moisture content of the field were measured by taking several soil samples from different depths of 10,15, 20 and $25 \mathrm{~cm}$ at various locations of the field. The samples were raised from the soil by employing a cylindrical sampler, and to conserve moisture content from evaporating during transporting to the laboratory, they were immediately 
placed in plastic bags. It was weighted before and after drying in an oven at $105^{\circ} \mathrm{C}$.

Moisture content and bulk density were calculated based on equations 1 and 2, respectively. The average soil moisture content and bulk density were $14.45 \%$ and 1.257 g.cm ${ }^{3}$, respectively.

$M C=\frac{W B-W A}{W B} \times 100$

Where:

$M C$ : Moisture Content (\%).

WB: Wet weight of soil sample (g).

WA: Dry wet of soil sample (g).

$B D=m s / V c$

Where:

$B D$ : Bulk density $\left(\right.$ g. $\left.\mathrm{cm}^{-3}\right)$.

$m s$ : Dry weight of soil in the cylinder (g).
$V c$ : Cylinder volume $\left(\mathrm{cm}^{3}\right)$.

Cone index $(\mathrm{CI})$ considers as an indicator for soil strength. CI and its gradient with respect to penetration depth have been utilized as a basis for simulating off-road vehicle performance. CI readings were taken from a penetrometer data according to ASABE S313.2 standards with a conical base area of $0.130 \mathrm{~cm}^{2}$ and angle of $30^{\circ}$ (ASABE, 2009) for a specified range of depths (5-25 $\mathrm{cm}$ ) with increments of $5 \mathrm{~cm}$ interval for each measurement in several areas of the field. The mean CI for two sites were 550 and $980 \mathrm{kPa}$.

\section{Tractor and tillage equipment:}

A two- drive wheel tractor was used in this study (model: CASE JX75T, India) to supply power for pulling the used plough in the experiments. The practical characteristics of the used tractor are illustrated in table (1).

Table (1). Characteristics of the used tractor in the experiments.

\begin{tabular}{lc}
\hline Characteristics & CASE JX75T Model \\
\hline No. of cylinders & 4 CYL \\
\hline Power (kW / hp) @ 2500 rpm & $75 / 55$ \\
\hline Max. torque (Nm @ rpm) & 242 Nm @ 1500 rpm \\
\hline Fuel Tank Capacity (Litre) & 62 \\
\hline Transmission clutch & Mechanical \\
\hline Total number of speeds & 8 forward, 2 reverse \\
\hline PTO speeds (rpm) & 2160/2200 \\
\hline Wheelbase 2WD / 4WD (mm) & 555 \\
\hline Ground clearance under rear axle (mm) & $16-7.5 / 30-16.9$ \\
\hline Type Size 2WD Front/Back
\end{tabular}

A chisel plough implement was applied for field experiments. The implement included seven spring crooked shanks linked to a frame in two rows. The width of each shank was 60 $\mathrm{mm}$. Also, the working width of the plough was $1650 \mathrm{~mm}$. Angle of attack for each shank was $25^{\circ}$. Before the experiments, technical adjustments were achieved for the chisel plough and the tractor. The chisel plough was eventually linked to the tractor using the three-point hitch links of the tractor. 


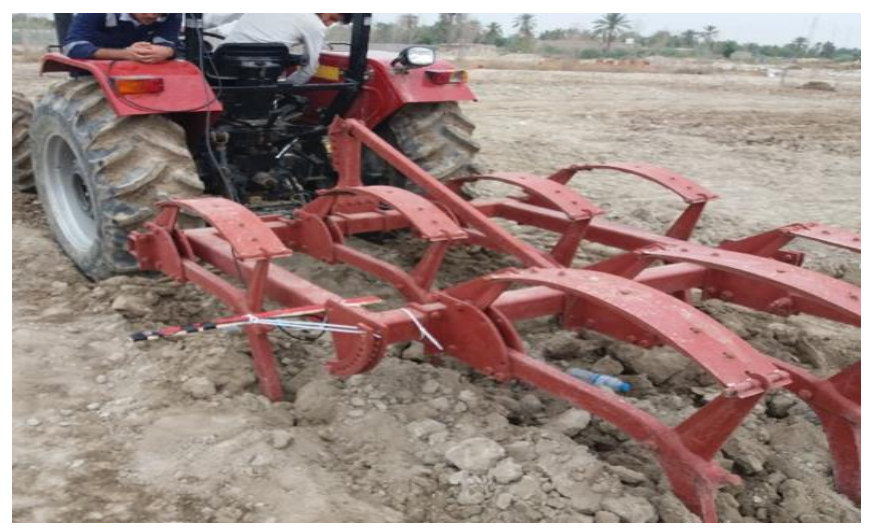

Fig. (1): A conventional tillage system used in the experiments.

\section{Field experiments}

A conventional tillage system was used in this study (Fig. 1) which includes a chisel plough. The experiments were executed in the farmland under different field conditions utilizing four depths of chisel plough $(10,15$, 20 and $25 \mathrm{~cm}$ ), three speeds of the tractor $\left(0.54,0.83\right.$ and $\left.1.53 \mathrm{~m} \mathrm{sec}^{-1}\right)$ and two levels of CI (550 and $980 \mathrm{kPa})$. All tests had three replications producing in a total of 72 experiments. Prior to each experiment, a training zone was chosen to get stable case of forward speed and tillage depth. A required tillage depth was practically accomplished by setting the level of chisel plough horizontally relative to the surface of the soil in a training zone of the field. Moreover, to achieve correct forward speed, the tractor was moved fivemeter to reach the required forward speed for testing in a training zone. Slippage of the tractor is generally calculated by measuring the theoretical velocity, which represents the speed of the tractor without loading (without plowing), and the actual velocity, which represents the speed of the tractor when the plow in the operating position (with plowing) according to the following formula (3) (ASAE, 2003).

$S=\left(1-\frac{V a}{V t}\right) \times 100$
Where:

$S$ : Slippage (\%)

$V a$ : Actual velocity $\left(\mathrm{m} \cdot \mathrm{sec}^{-1}\right)$

$V t$ : Theoretical velocity $\left(\mathrm{m} \cdot \mathrm{sec}^{-1}\right)$

\section{Mathematical Model}

In this study, Design Expert software (Version: 8.0.6.1) was utilized for developing the mathematical model of slippage for the tractor. A total of 72 tests were carried out under different field conditions. Three independent parameters, including tillage depth $(10,15,20$, and $25 \mathrm{~cm})$, forward speed $\left(0.54,0.83\right.$, and $\left.1.53 \mathrm{~m} . \mathrm{sec}^{-1}\right)$ and the cone index $(550$, and $980 \mathrm{kPa})$, were used in the present study to produce acceptable models of slippage of the tractor. To evaluate the significance of the studied parameters on the slippage of tractor, the ANOVA approach was utilized. Table 2 illustrates the experimental ranges of the independent parameters and their coded values. Design Expert software was used for selecting more powerful and more reliable models. Also, an assortment of several polynomial models was examined. The stepwise algorithm, as one of the most widely used variable selection techniques, was utilized for optimizing and reducing the magnitude of the expected regressors, (Montgomery \& Runger, 2014) (Table 3). 
Table (2). The ranges of the independent parameters for predicting slippage in the present study

\begin{tabular}{ccccc}
\hline & & \multicolumn{3}{c}{ Levels of coded parameters } \\
\hline Parameters & Units & $\mathbf{- 1}$ & $\mathbf{0}$ & $\mathbf{1}$ \\
\hline Tillage Depth & $\mathrm{cm}$ & 10 & 17.5 & 25 \\
\hline Speed & $\mathrm{m} \cdot \mathrm{sec}^{-1}$ & 0.54 & 0.97 & 1.53 \\
\hline Cone Index & $\mathrm{kPa}$ & 550 & 765 & 980 \\
\hline
\end{tabular}

Table (3): Summary of statistics of reduced quadratic models.

\begin{tabular}{lllc}
\hline Std. Dev. & 0.16 & R-Squared & 0.971 \\
\hline Mean & 4.01 & Adj R-Squared & 0.967 \\
\hline C.V. \% & 3.97 & Pred R-Squared & 0.928 \\
\hline PRESS & 2.10 & Adeq Precision & 62.52 \\
\hline
\end{tabular}

\section{Results and Discussion}

Table (4) explains the freedom degree (df), the sum of squares, F-value, and probability level for all studied parameters for predicting slippage of the tractor during field procedures according to ANOVA investigation.
According to the obtained results, the single effects of the treatments on the slippage were highly significant $(\mathrm{P}<0.0001)$. Moreover, interaction of the parameters was significant at level of 0.05 . As a consequence, slippage can be considered a function of tillage depth, $\mathrm{CI}$, and forward speed of the tractor.

Table (4): ANOVA approach for slippage of tractor.

\begin{tabular}{ccccc}
\hline Source & Sum of Squares & df & F- Value & p-value Prob $>$ F \\
\hline Model & 53.75 & 6 & 266.27 & $<0.0001$ \\
\hline Cone index & 4.06 & 1 & 160.81 & $<0.0001$ \\
\hline Depth & 24.51 & 1 & 971.32 & $<0.0001$ \\
\hline Speed & 5.51 & 1 & 218.52 & $<0.0001$ \\
\hline Cone index-Depth & 0.057 & 1 & 2.76 & 0.0256 \\
\hline Cone index-Speed & $1.797 \mathrm{E}-003$ & 1 & 1.73 & 0.0429 \\
\hline Depth-Speed & 0.116 & 1 & 54.67 & 0.0121 \\
\hline
\end{tabular}

Fig. (2) Illustrated the importance of each variable on slippage of tractor during tillage operations. As can be shown in Fig. (2), the most effective factors on slippage was tillage depth then forward speed and CI, respectively. Hence, it is predictable that the single impact of tillage depth on the slippage is more than that interaction of speed and CI. Also, it can be noticed that CI inversely affected the slippage of the tractor. 
Design-Experti Software Factor Coding: Actual Original Scale Slippage

Actual Factors

A: Cone index $=765.00$

B: Depth $=17.50$

C: speed $=1.19$

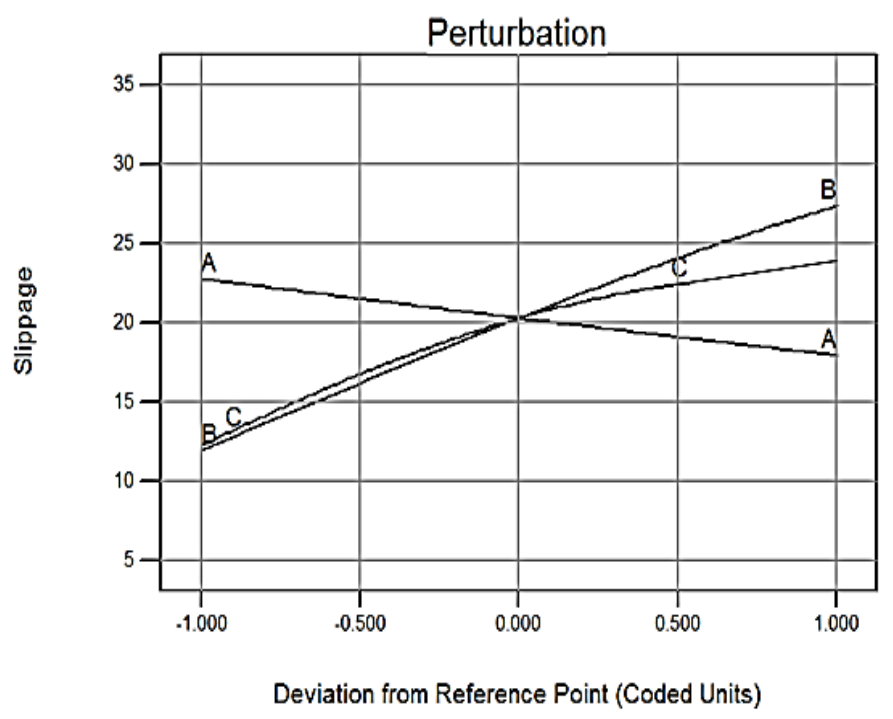

Fig. (2): Perturbation plot of slippage.
Fig. (3) showed the effect of CI, tillage depth and their interaction on the slippage of the tractor. Slippage was reduced by $34 \%$ when CI increased, CI is considering as the criterion for soil strength which means rising cohesion of soil components and friction between soil particles, with increasing the CI value, it is more difficult to overcome the internal forces of the soil and thus slippage is reduced. Moreover, with increasing the tillage depth up to $25 \mathrm{~cm}$, the slippage of tractor varied progressively from the lowest rate to the highest rate by about $187 \%$. This may be due to the increased required drawbar pull and drawing the plough at the great tillage depth. Increase of draft force of plough led to raising net traction which lead to boost of movement of soil particles. The highest value of slippage was $29 \%$ which occurred at the tillage depth of $25 \mathrm{~cm}$ and $\mathrm{CI}$ value of $550 \mathrm{kPa}$.

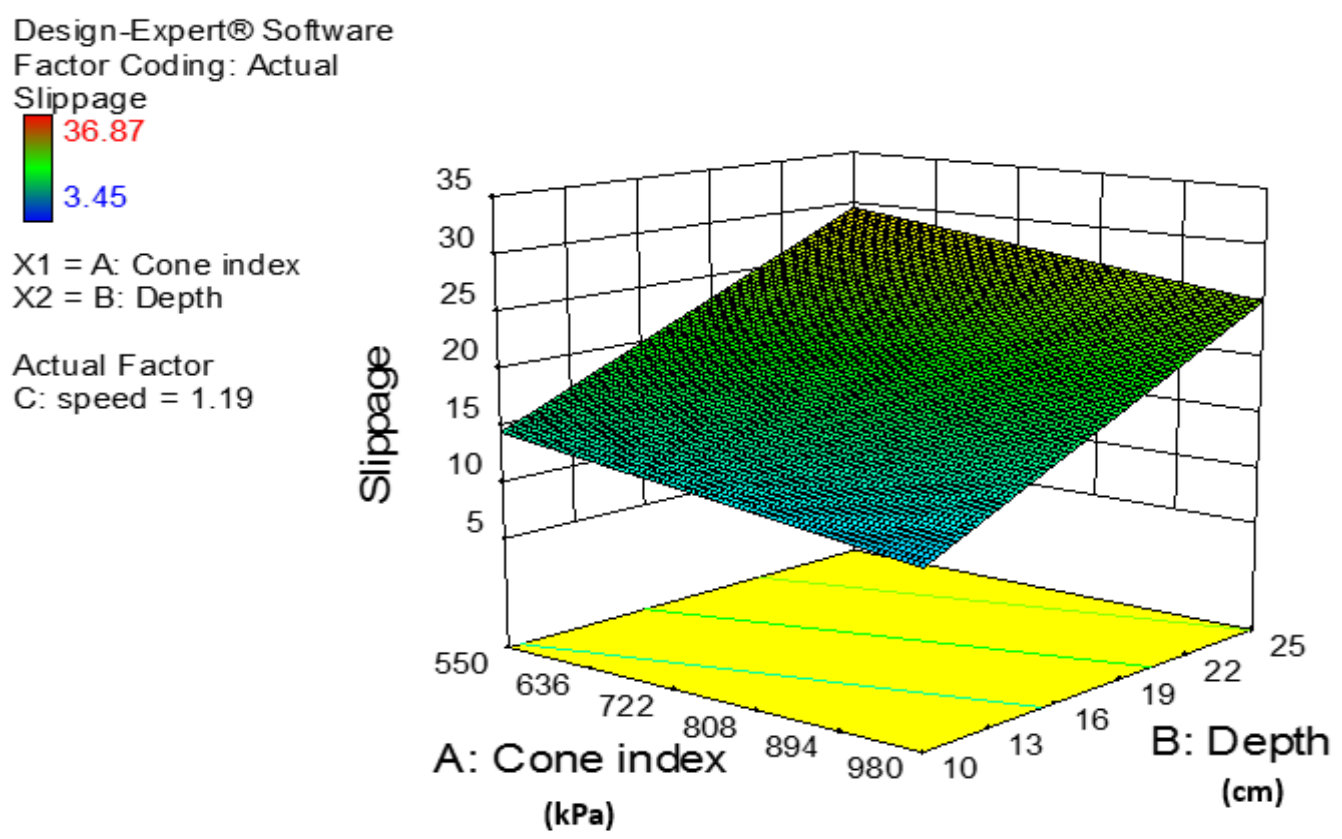

Fig. (3): Impact of cone index and tillage depth on slippage of tractor. 
When comparing the results of this study with previous studies, great conformity was found in the results obtained (Zoz \& Grisso, 2003; Kumar et al., 2017; Janulevičius et al., 2018). The effect of cone index and forward speed and dual combination effect of them on slippage of tractor are depicted in Figure 4. The results showed the increasing trend of slippage of tractor with increasing forward speed during field experimentations. It can be seen that when speed increased from 0.54 to
$1.53 \mathrm{~m} \mathrm{sec}^{-1}$ produced a significant increase in the slippage of tractor by approximately $116 \%$. This goes back to increasing drawbar pull for moving plough with increment of forward speed. Hence, drawbar pull produced by the tractor may be insufficient and as a result, the slippage of tractor increase. The biggest slippage produced from interaction of CI and forward speed was $25 \%$ at CI value of $550 \mathrm{kPa}$ and forward speed value of 1.53 $\mathrm{m} \cdot \mathrm{sec}^{-1}$.

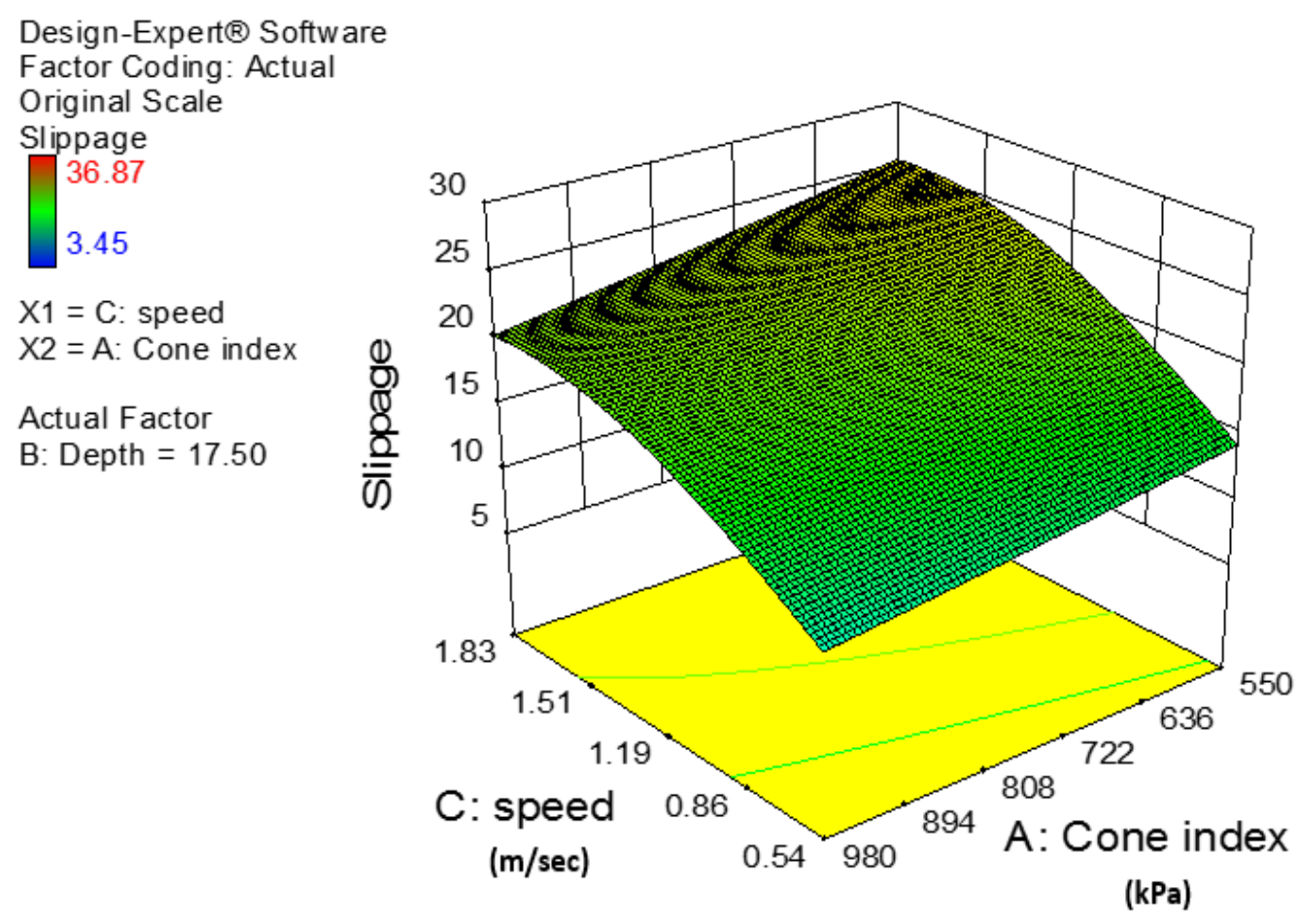

Fig. (4): Impact of cone index and speed on slippage of tractor.

Fig. (5) demonstrated the impact of forward speed and tillage depth and binary interaction of them on slippage of tractor. The effect of concurrent change of tillage depth and forward speed led to $433 \%$ increment of the tractor slippage which occurred at tillage depth of $25 \mathrm{~cm}$ and forward speed of $1.53 \mathrm{~m}$ $\sec ^{-1}$. 


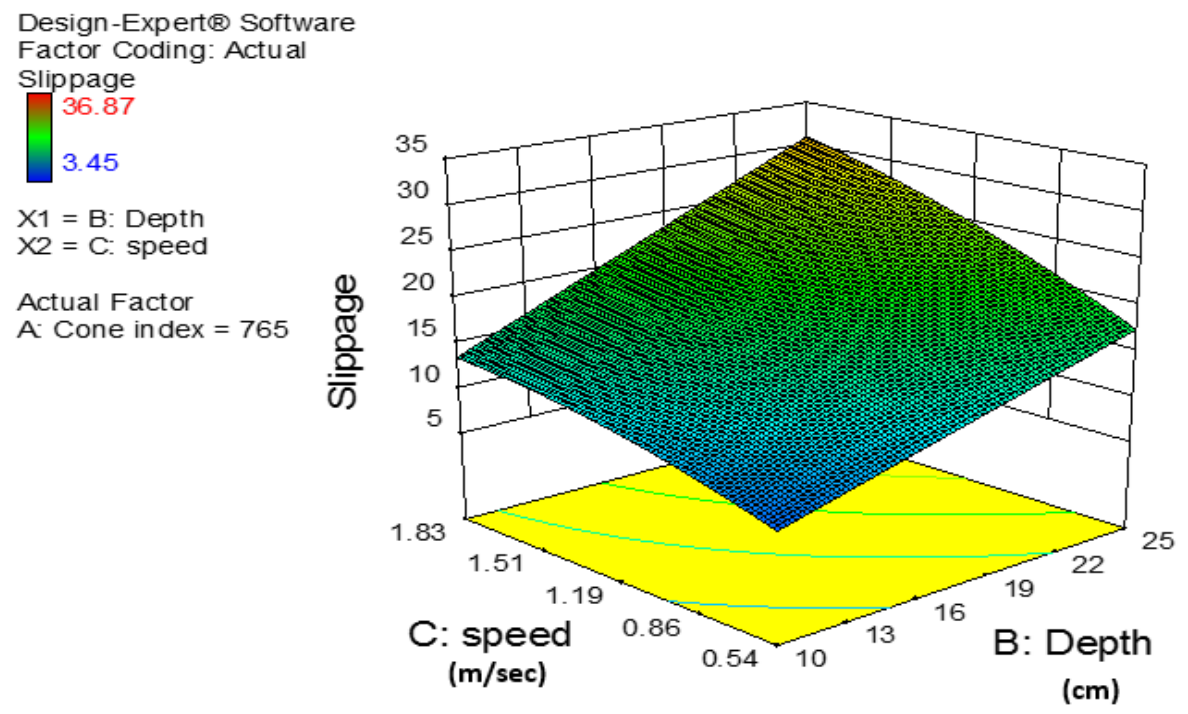

Fig. (5): Impact of tillage depth and speed on slippage of tractor.

Fig. (6) Illustrates the regression analysis of the tractor slippage under various field conditions. The data points spread nearly at 1:1 line and it is apparent that the developed model has a suitable robustness and executes successfully compared to the real data. Fig. (7) demonstrated the relationship between internally student zed residuals and run number for the data. The analysis of data showed that all of readings were within the correct domain which confirm accuracy of the model to predict slippage of tractor under various field conditions. The fitted model for slippage prediction is presented by following equation.

$$
\begin{aligned}
\text { Sqrt }(\text { Slippage })= & +0.47821-1.25950 \mathrm{E}-003 * \text { cone index } \\
& +0.19724 * \text { depth }+2.77690 * \text { speed } \\
& +0.016802 * \text { depth } * \text { speed } \\
& -2.83577 \mathrm{E}-003 * \text { depth }^{2} \\
& -0.87796 * \text { speed }^{2}
\end{aligned}
$$

Design-Expert@ Software Slippage

Color points by value of Slippage:

36.87

3.45

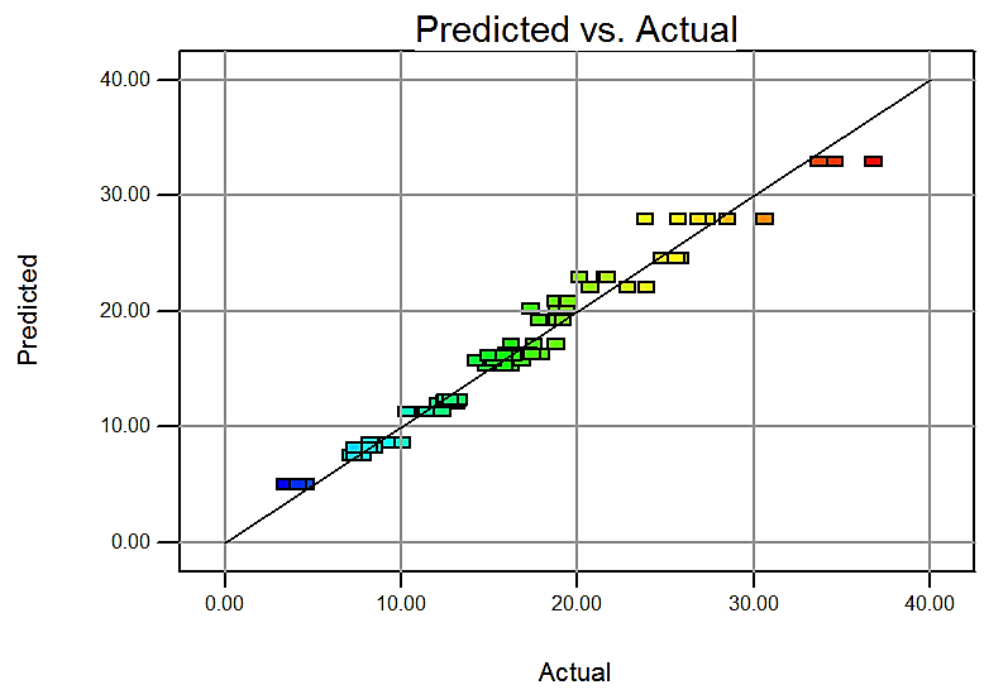

Fig. (6): The correlation between actual and predicted of tractor slippage. 


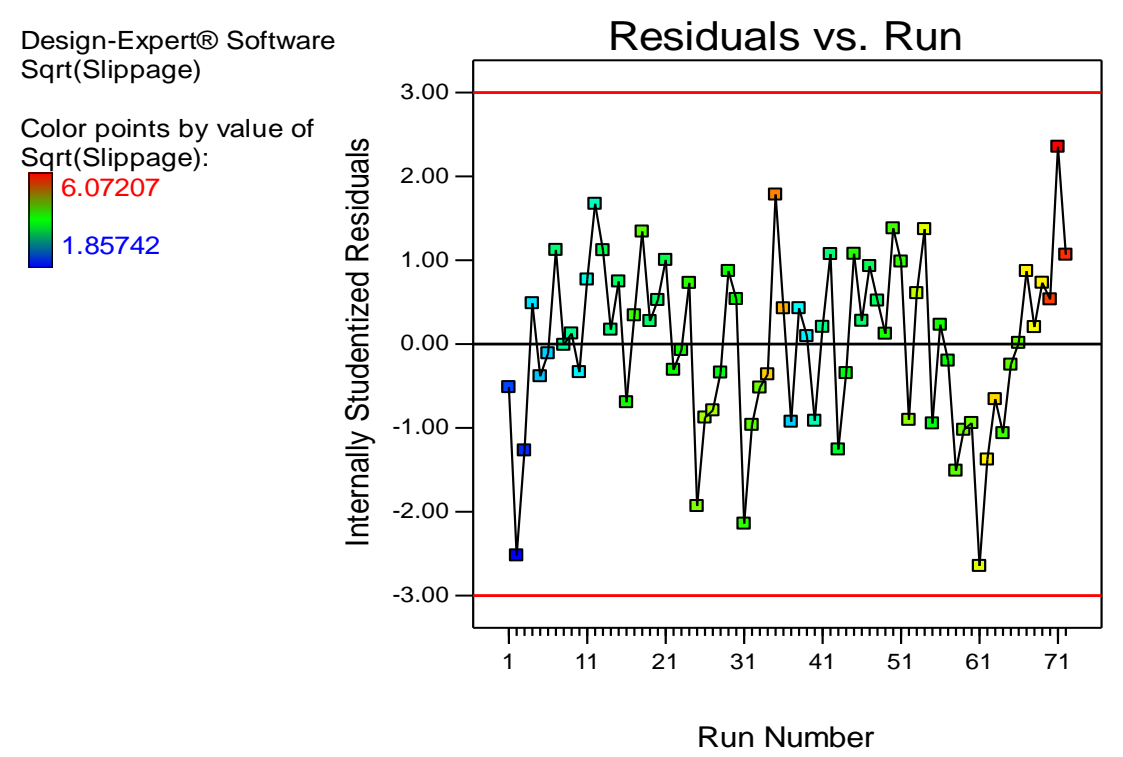

Fig. (7). The internally student zed residuals versus run number

\section{Conclusion}

This research presents a mathematical model for predicting slippage of the tractor under different field conditions. Design Expert software was used to develop powerful and reliable models. On the basis of statistical performance of data, the single effects of the treatments and interactions of the factors on the slippage were significant. The results showed that the most effect of studied factors on slippage was tillage depth then speed and CI, respectively. Ultimately, it can be claimed that the mathematical model can be proposed to predict slippage of tractor because of the accurate and reliable results.

\section{Acknowledgments}

This paper was supported by University of Basrah, College of Agriculture, Department of Agriculture Machines and Equipment.

ORCID: Salim A. Almaliki:

https://orcid.org/0000-0002-9115-7518

Majed S. Himoud

https://orcid.org/0000-0003-3551-7336

Sadiq J. Muhsin

https://orcid.org/0000-0001-9512-9947

\section{References}

Aday, S. H., Muhsin, S. J. \& Bander, S. A. (2011). Determination the Draft ranges at which $2 \mathrm{WD}$ and 4WD tractors operate at their maximum traction efficiency. Basrah Journal of Agricultural Science, 24(2), 22 - 29.

https://cutt.ly/BfMlJ5B

Almaliki, S. (2017). Development and Evaluation of Models for MF-285 Tractor Performance Parameters Using Computational Intelligence Techniques. Ph. D. Thesis. University of Tehran, Iran, 215pp.

Almaliki, S. (2018). Simulation of draft force for three types of plow using response surface method under various field conditions. Iraqi Journal of Agricultural Sciences 49, 1123-1131. https://doi.org/10.36103/ijas.v49i6.151

Almaliki, S., Alimardani, R. \& Omid, M. (2016). Fuel consumption models of MF285 tractor under various field conditions. Agricultural Engineering International: CIGR Journal, 18, 147-158. https://cutt.ly/JfMlM20

Almaliki, S., Himoud, M., \& Muhsin, S. (2019). A stepwise regression algorithm for prognostication draft requirements of disk plough. Journal of Engineering and Applied Sciences, 14, 1033510340.

https://doi.org/10.36478/jeasci.2019.10335.10340 


\section{Almaliki et al./Basrah J. Agric. Sci., 34(1): 49-59, 2021}

ASABE, Standard. (2009). ASAE D497.6 Agricultural Machinery Management Data. ASAE. St. Joseph. MI:49085,1-8.

https://cutt.ly/EfMlj1q

ASAE, (2003). ANSI/ASAE S296.5 DEC. 2003 (R2018) General Terminology for Traction of Agricultural Traction and Transport Devices and Vehicles. MI, USA: ASAE, St. Joseph. https://cutt.ly/ofMzqC9

Barbosa, L. A. P., \& Magalhaes, P. S. G. (2015). Tire tread pattern design trigger on the stress distribution over rigid surfaces and soil compaction. Journal of Terramechanics, 58, 27-38.

https://doi.org/10.1016/j.jterra.2014.12.006

Battiato, A., \& Diserens, E. (2013). Influence of tyre inflation pressure and wheel load on the traction performance of a $65 \mathrm{~kW}$ MFWD tractor on a cohesive soil. Journal of Agricultural Science, 5, 197-215.

https://doi.org/10.5539/jas.v5n8p197

Battiato, A., \& Diserens, E. (2017). Tractor traction performance simulation on differently textured soils and validation: A basic study to make traction and energy requirements accessible to the practice. Soil \& Tillage Research, 166, 18-32. https://doi.org/10.1016/j.still.2016.09.005

Damanauskas, V., \& Janulevicius, A. (2015). Differences in tractor performance parameters between single-wheel 4WD and dual-wheel 2WD driving systems. Journal of Terramechanics; 60 , 63-73.

https://doi.org/10.1016/j.jterra.2015.06.001

Damanauskas, V., Janulevicius, A., \& Pupinis, G. (2015). Influence of extra weight and tire pressure on fuel consumption at normal tractor slippage. Journal of Agricultural Science, Vol. 7, No. 2, 5567.

http://dx.doi.org/10.5539/jas.v7n2p55

Janulevičius A., Damanauskas V., \& Pupinis, G. (2018). Effect of variations in front wheels driving lead on performance of a farm tractor with mechanical front-wheel-drive. Journal of Terramechanics, 77, 23-30. https://doi.org/10.1016/j.jterra.2018.02.002

Karparvarfard, S. H. \& Rahmanian-Koushkaki, H. (2015). Development of a fuel consumption equation: Test case for a tractor chisel-ploughing in a clay loam soil. Biosystems Engineering; 130,2333.https://doi.org/10.1016/j.biosystemseng.2014.11. 015

Kumar, A., Tewari, V. K., Gupta, C., \& Pareek, C. M. (2017). A device to measure wheel slip to improve the fuel efficiency of off road vehicles. Journal of Terramechanics, 70, 1-11. https://doi.org/10.1016/j.jterra.2016.11.002

Lee, J. W., Kim, J. S., \& Kim, K. U. (2016). Computer simulations to maximise fuel efficiency and work performance of agricultural tractors in rotating and ploughing operations. Biosystems engineering, 142, $1-11$. https://doi.org/10.1016/j.biosystemseng.2015.11.01 2

Moitzi, G., Wagentristl, K., Refenner, H., Weingartmann, G., Piringer, J., Boxberger, A., \& Gronauer, H. (2014). Effects of working depth and wheel slip on fuel consumption of selected tillage implements. Agricultural Engineering International: CIGR Journal 16, 182-190. https://cutt.ly/ufMzJOY

Montgomery, D. C., \& Runger, G. C. (2014). Applied Statistics and Probability for Engineers. John Wiley \& Sons, Inc., Hoboken, NJ, xvi, $6^{\text {th }}$ edition, $765 \mathrm{pp}$.

Muhsin, S. J. (2010). Studying the power losses of two and four wheel drive tractors (2WD and 4WD) of massy ferguson (2680). Journal of Basrah Researches (Sciences), 36, 59-66. https://cutt.ly/qfMgoLj

Shafaei, S. M., Loghavi, M., \& Kamgar, S. (2018). A comparative study between mathematical models and the ANN data mining technique in draft force prediction of disk plow implement in clay loam soil. Agricultural Engineering International: CIGR Journal, 20, 71-79. https://cutt.ly/ZfMz9Yq

Shafaei, S. M., Loghavi, M., \& Kamgar, S. (2019). Feasibility of implementation of intelligent simulation configurations based on data mining methodologies for prediction of tractor wheel slip. Information Processing in Agriculture, 6, 183-199. https://doi.org/10.1016/j.inpa.2018.10.004

Šmerda, T., \& Čupera, J. (2010). Tire inflation and its influence on drawbar characteristics and 
performance- energetic indicators of a tractor set. Journal of Terramechanics; 47, 395-400. https://doi.org/10.1016/j.jterra.2010.02.005

Taghavifar, H., \& Mardani, A. (2015). Evaluating the effect of tire parameters on required drawbar pull energy model using adaptive neuro-fuzzy inference system. Energy, 85, 586-593.

https://doi.org/10.1016/j.energy.2015.03.072
Wong, J. Y. (2009). Terramechanics and off-road vehicle engineering. 2nd edition. Amsterdam, Elsevier, 488pp. https://doi.org/10.1016/C2009-0-00403-6

Zoz, F. M., \& Grisso, R. D. (2003). Traction and tractor performance. ASAE Published, USA., No. 12 , $48 p p$.

https://www.academia.edu/26668729/ASAE

\title{
نماذج رياضية لتقييم انزلاق الجرار (CASE JX75T) في ظروف حقلية مختلفة
}

\author{
سالم عجر المالكي ، ماجد صالح حمود و صادق جبار محسن \\ قسم المكائن والآلات الزراعية، كلية الزر اعة، جامعة البصرة، العراق
}

المستخلص: يعد الانزلاق معيارًا أساسيًا لتقييم استهلاك الوقود والأداء الحقلي للجرار. الهدف من هذا البحث هو تطوير نموذج رياضي باستخدام برنامج Design Expert للندذجة والتتبؤ بانزلاق جرار CASE JX75T في ظروف تثغيلية مختلفة. تم استخدام المحراث الحفار كأداة تحميل للجرار الزراعي تحت أربعة أعماق حراثة وثلاثة مستويات للسرعة الامامية ومستويين من معامل المخروط في تربة ذات نسجة طينية غرينية. أجريت التجارب في موقع جامعة البصرة. تم تحليل النتائج التي تم الحصول عليها من العمل الميداني لتطوير نماذج ومعادلات رياضية للتبؤ وتقييم أداء الجرار عند حدوث عملية الانزلاق. وفقًا للنتائج التي تم الحصول عليها ، كانت التأثيرات الفردية للمعلمات (دليل المخروط ، وعمق الحراثة ، والسرعة الأمامية) على الانزلاق كبيرة جدًا تحت مستوى احتمالية (P P) (P). علاوة على ذلك، كانت التأثيرات المزدوجة للمعلمات المدروسة معنوية تحت مستوى احتمالية (0.05> p). زاد انزلاق الجرار بنسبة (187 و116 \%) مع زيادة عمق الحرث الى 25 سم والسرعة الأمامية إلى 1.53 م. ثانية-1 على التوالي. من ناحية أخرى، انخفض انزلاق الجرار بنسبة 34٪ عندما زاد مؤشر المخروط الى 980 كيلو باسكال. أظهر تحليل البيانات أن النموذج المختار يتمتع بقدرة محاكاة مقبولة ويتم تتفيذه بشكل ممتاز بالمقارنة مع النتائج الفعلية. وهذا يؤكد دقة النموذج للتنبؤ بانزلاق الجرار تحت ظروف حقلية مختلفة. الكلمات المفتاحية: Design Expert software ، الندذجة ، ظروف تثغيلية مختلفة، دليل المخروط. 